DOI: https://doi.org/10.47405/mjssh.v6i9.1014

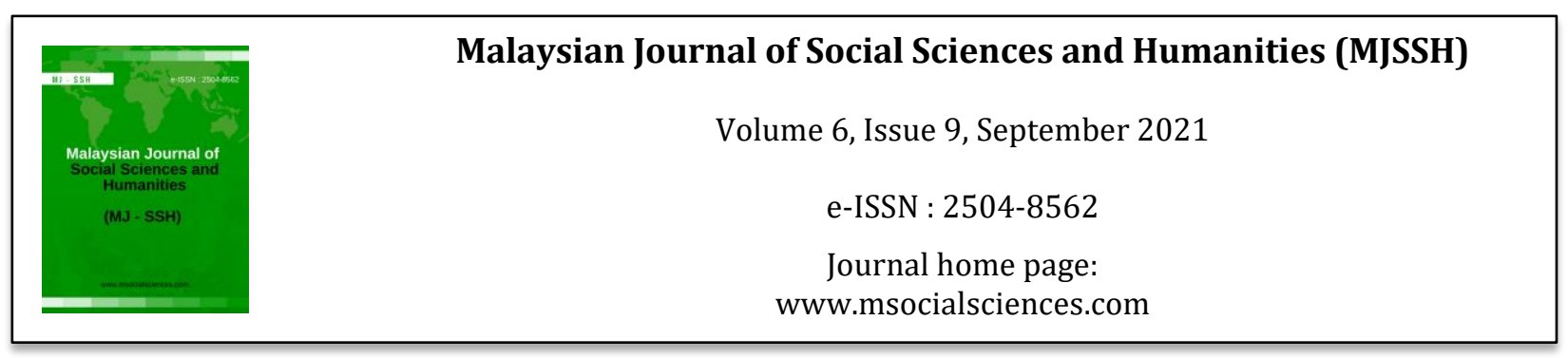

\title{
Developing Instagram Marketing Strategy in Sleep Aid Industry: A Study Case of Savlee Indonesia
}

\author{
Cicelia Susanti Sri Rejeki ${ }^{1}$ \\ ${ }^{1}$ School of Business and Management, Bandung Institute of Technology, Indonesia \\ Correspondence: Cicelia Susanti Sri Rejeki (ciceliasusanti@gmail.com)
}

\begin{abstract}
The rising of COVID-19 pandemic in Indonesia affected to higher awareness on health issue including sleeping issue. It also caused higher internet penetration including on shifting offline business to digital platform including social media. Savlee is Indonesian company which is combining neuroscience, pharmaceutical, and psychological approach on producing sleep aid products using natural ingredients and running its business primarily on Instagram. As a small business which utilize Instagram as its primary marketing channel, Savlee gains opportunity to turn the phenomenon of shifting behavior as an advantage. In order to stand out on social media and grab market awareness, this study aims to assess, improve, and optimize the performance of Savlee's Instagram marketing strategy. An Instagram marketing should be developed by considering latest trend on social media, characteristic and needs of audience, and vision of Savlee. This study is conducted using problem solving method by assessing external and internal factors that affected Instagram marketing strategy of Savlee and narrowing down the finding of the research as root causes using Fishbone analysis. As a result, the implication of this research is gained implemented solutions and its action plan on penetrating more engaging and effective Instagram marketing strategy which require financial support and improvement on human resource's skills.
\end{abstract}

Keywords: instagram marketing strategy, sleep aid industry, online engagement

\section{Introduction}

Sleeping has been proven as basic need of human as eating and drinking which should be fulfilled. In fact, sleep plays a big role in cognitive, somatic, and psychological process which optimize body performance and develop more stable mental condition. A study by Sleep Association (2018) indicated that 50 to 70 million U.S. Adults experience sleep disorders including insomnia, snoring, and sleep apnea. Sleeping problem is also commonly found in Indonesia. The prevalence of insomnia survivors in Indonesia reached 28 million adults in 2004 and estimated to grow (Detik Health, 2010) particularly after the emergence of pandemic in early 2020. As a local brand in sleep aid industry in Indonesia, Savlee is aware of the rising of sleeping issues and taking the opportunity to penetrate a solution by providing a high-quality sleep aid with natural ingredient to prevent side effects and addiction. In order to scale the business and gain recognition from broader potential market, Savlee decided to penetrate marketing strategy through Instagram. Moreover, pandemic forces customer to get accustomed to online shopping and forces sleeping aid businesses in Indonesia to expand to online platform especially Instagram. Researcher assumes most of small businesses use Instagram due to the big opportunity to be exposed to potential market with a relatively low budget as it is a very suitable channel to interact with 
the audience, gain recognition, and reach potential market without being charge (Musonera, 2018). Additionally, Instagram provides many free-to-used features including IG Feed, IG Story, IG Live, IGTV, and long caption, to accommodate SMEs to grow the business. Since Instagram has been a very affordable tool for SMEs to advocate value and inclusion to strategic planning (Rapp, et al., 2013), researcher need to develop Instagram marketing strategy which works effectively and efficiently for Savlee to increase online traffic and brand awareness.

\section{Business Issue Faced}

Savlee is a local brand who aims to produce innovation to solve sleeping issue with natural ingredient. The company was established in January 2020 and launched its first product in July 2020 through Instagram. Savlee has executed various different types of Instagram marketing strategy including set up Facebook business account and link it to Instagram, conduct content posting schedule, and post several content types. Contrary, this marketing strategies does not give feedback as expected. Low engagement on Instagram account of Savlee indicated an ineffective plan and execution of Instagram marketing strategy. It causes the audience barely find Savlee's content on their Instagram home and interact with the content. In result, the audience are unaware with the brand and it impacted to the stagnant sales. Savlee finds it hard to figure out what kind of Instagram strategy that work best to attract interaction with followers and increase online engagement on the brand page. The company requires to identify factors to create an engaging Instagram marketing strategy to accelerate engagement in order to survive on social media. Therefore, researcher conduct in-depth research to assess and evaluate contributed factors which affected performance of Instagram account of Savlee and its competitor to gather insightful data to develop engaging Instagram marketing strategy. The output of this research is to find the best alternative of Instagram marketing strategy to gain recognition from potential audience and also indirectly convert them as a customer.

\section{Methodology}

\section{Business Issue Exploration}

Business issue exploration is obtained by conducting analysis on external and internal environmental factors. External analysis observes industrial environment of company and can be assessed using PESTEL Analysis, Porter's 5 Forces, and Customer Insight. Internal analysis is used to investigate the organization and business process of Savlee. This analysis can be assessed using company analysis by evaluating departments' performance and content analysis by evaluating data performance of commercial content on Instagram.

\section{SWOT Analysis}

SWOT Analysis is an assessment method to identify four characteristics of a business namely Strength, Weakness, Opportunity, and Threat. The results of obtained assessment will be crystallized in SWOT Analysis. Result of external analysis identifies opportunities and risks faced in the industry, while internal analysis measures the strengths and weaknesses of the company based on resources. The aims of conducting SWOT Analysis are to assess the ability and feasibility of Savlee to grab opportunities and mitigate risk.

\section{Root Cause Analysis}

A company must recognize the root of the problem and take on a deeper analysis to eliminate the cause, because if the root cause has not been recognized thus symptoms that address the problem will likely remain happening (Doggett, A., 2005). According to that, recognizing root problem will help to map the most suitable method to solve the issue. The researcher uses fishbone diagram as a framework to identify the cause and effect of particular problem in Savlee. 


\section{Conceptual Framework}

Conceptual framework is analytical tool to illustrate the association between concepts of the study. It is organized in a plausible structure to portrait or visualize how the notion of a research relate to one another (Grant \& Osanloo, 2014). Savlee faced an insignificant impact of current Instagram marketing strategy that has been executed. This condition is an accumulation of several factors both from external and internal environment of Savlee that affected one another. Business issue analysis including external and internal analysis is applied to map the business problems faced. Researcher requires to explore the business issue by conduction external and internal analysis of Savlee to evaluate root cause of ineffective Savlee's Instagram marketing strategy. The congregate data is concluded as strength, weakness, opportunity, and threat of Savlee and will be determine as the root cause of this study.

Figure 1: Conceptual Framework

\section{BUSINESS ISSUE EXPLORATION}

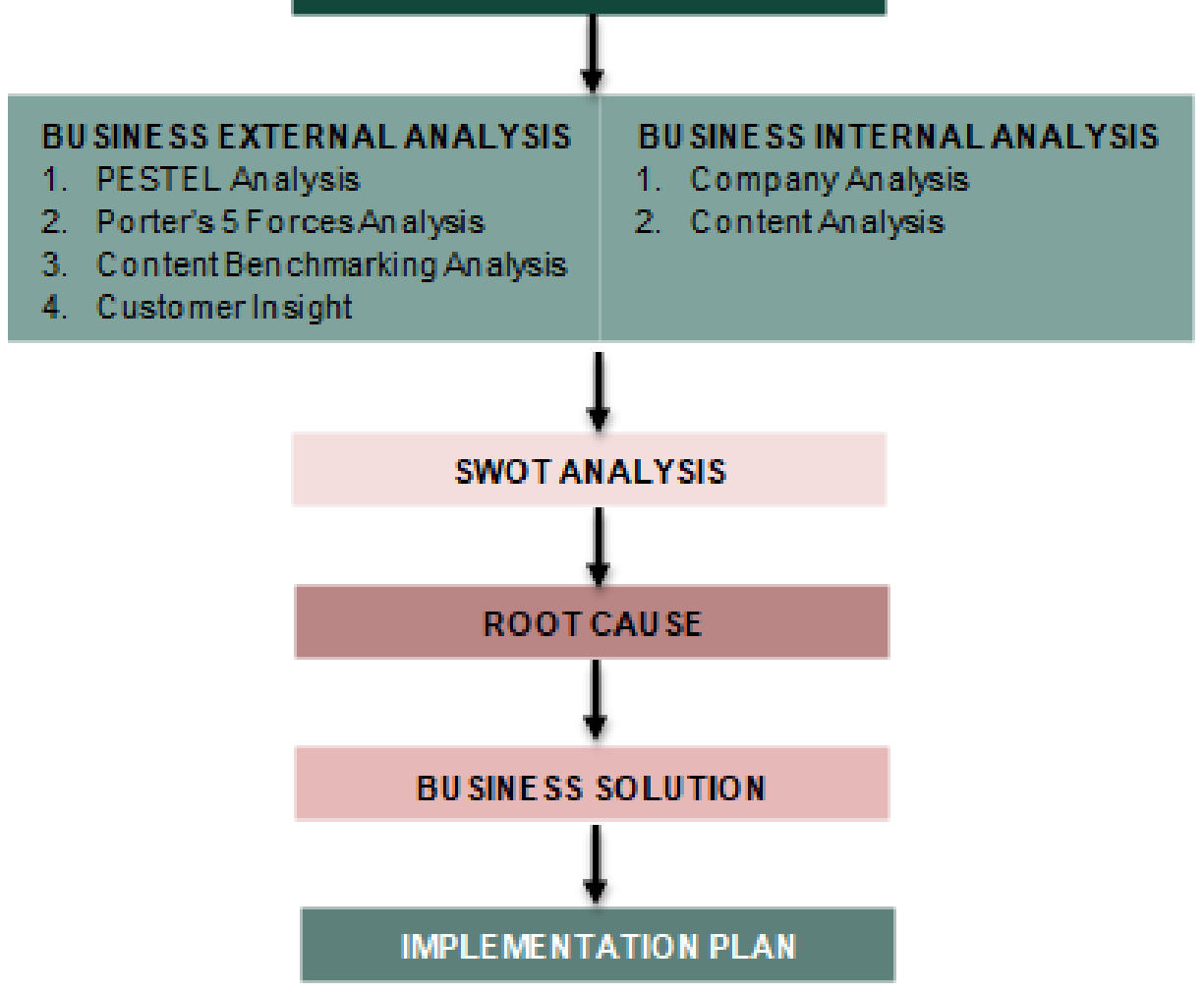

\section{Analysis and Result}

\section{Root Cause Analysis Result}

Researcher found a gap between ideal state on implementation plan of Instagram marketing strategy and result of the implementation plan. Figure 2 shows there are four categories of root cause problem that affecting Instagram marketing strategy of Savlee including Human Resource, Content, Marketing, and Finance. As a result of all root causes, all marketing strategy that has been planned cannot be performed optimally and become ineffective and impact less Instagram marketing strategy. 
Figure 2: Root Cause Analysis



\section{Business Solution Alternatives}

As an impact of previous root causes, Savlee should find solutions to solve ineffective and impact less Instagram marketing strategy. Several alternative solutions and its feasibility to be executed to the current condition of Savlee will be proposed to solve this problem. As the root cause of the problem is happening because Savlee are lack of knowledge on the characteristic of its audience on Instagram, the solution provided will be focused on new Instagram marketing strategy which will be more impactful with several limitation owns by the company including broaden knowledge on sleep aid industry, increase the technical skill of Savlee's marketing team, develop Savlee's Instagram Marketing, Boost Reach of Savlee's Instagram, and Gather additional marketing fund.

\section{Discussion and Implementation Plan}

\section{Broaden Knowledge in Sleep Aid Industry}

As a team who run business in sleep aid industry, Savlee's employee should have adequate knowledge about sleeping issue and sleep aid to provide a profound service for its customers. the marketing team is advised to join online sleeping issue community to gain broader insight and information about sleeping issue all around the world and be exposed to Polysomnography Experts and possibly build connection with them. Moreover, the discussion in this online community will be very varieties and covers personal experience and behavior that rarely explain on medical journal. As an advantage, Savlee's team can join these online communities for free through social media such as Facebook.

Table 1: Timeline and PIC of Joining Online Sleeping Issue Community

\begin{tabular}{lccc}
\hline \multicolumn{1}{c}{ Action } & Period & $\begin{array}{c}\text { Frequency } \\
\text { Or Duration }\end{array}$ & PIC \\
\hline $\begin{array}{l}\text { Join at least 1 local and international sleeping } \\
\text { issue community }\end{array}$ & September 2021 & One time event & \\
$\begin{array}{l}\text { Collect latest information about sleeping } \\
\begin{array}{l}\text { issue, sleep aid product, sleeping } \\
\text { behavior, etc. }\end{array}\end{array}$ & September 2021 & 1x/Week & Marketing \\
\hline
\end{tabular}




Connect with potential stakeholder in the $\quad$ September $2021 \quad 1 \mathrm{x} /$ Week
community

\section{Increase Technical Skill of Savlee's Marketing Team}

Marketing team of Savlee need to join training program to advance the skill of conducting more engaging and fresh marketing strategy. The team should master the basic information about Instagram marketing strategy and trick to create engaging content. There are several online courses that provide class slob technical and nontechnical perspective that cover Instagram marketing strategy with affordable price, implementative material, and flexible schedule including DNVB Indonesia. By subscribing to online courses as a method to perform training program, Savlee can also eliminate a prolonged process of conducting curriculum, training schedule, and hiring professional to perform the training program.

Table 2: Timeline and PIC of Conducting Internal Training using Paid Course

\begin{tabular}{lccc}
\hline \multicolumn{1}{c}{ Action } & Period & $\begin{array}{c}\text { Frequency } \\
\text { Or Duration }\end{array}$ & PIC \\
\hline $\begin{array}{l}\text { Subscribe to classes on online courses } \\
\text { that fit the need of Savlee's marketing } \\
\text { team }\end{array}$ & September 2021 & One time event & \\
$\begin{array}{l}\text { Run online training program based on } \\
\text { all employees' schedule availability } \\
\begin{array}{l}\text { Create a forum to discuss new knowledge } \\
\text { gain from the material }\end{array}\end{array}$ & October 2021 & 2x per 3 months & Marketing \\
\hline
\end{tabular}

On the other hand Looking at the slow progress on creating new content due to lack of capability on graphic designing and video editing in the marketing team, researcher advises Savlee to hire graphic designer and video editor interns. Working with interns is not only reduce the amount of time to produce a new content, but also add new perspective on content brainstorming to the team. It will help marketing team to. Considering the budget limitation to pay salary of interns, Savlee could provide free career preparation mentorship program as a benefit of internship.

Tabel 3: Timeline and PIC of Hiring Grapic Designer and Video Editor Intern

\begin{tabular}{lccc}
\hline \multicolumn{1}{c}{ Action } & Period & $\begin{array}{c}\text { Frequency } \\
\text { Or Duration }\end{array}$ & PIC \\
\hline $\begin{array}{l}\text { Prepare module of professional career } \\
\text { development mentorship program for } \\
\text { interns }\end{array}$ & September 2021 & 2 weeks & All division \\
$\begin{array}{l}\text { Determine requirement and job } \\
\text { description for each job position }\end{array}$ & September 2021 & 2 weeks & HR (CEO) \\
$\begin{array}{l}\text { Recruit and onboard the selected interns } \\
\begin{array}{l}\text { Conduct performance evaluation, job } \\
\text { compensation, and sharing session for } \\
\text { interns }\end{array}\end{array}$ October 2021 & Two days & $\begin{array}{r}\text { CEO and } \\
\text { Marketing }\end{array}$ \\
\hline
\end{tabular}

\section{Develop Savlee's Instagram Marketing}

Savlee is being restricted to create advertising content about sleep aid due to the formal advertising regulation in sleep aid industry in Indonesia. This formal regulation manages how a business people should execute an advertising to avoid false, misleading, and ambiguous information to its potential customer. Therefore, Savlee should be very as cautious in making advertising content and follows the regulation to prevent legal sue in the future. Researcher advice Savlee to develop internal content advertising regulation which follow regulation in Indonesia 
Table 4: Timeline and PIC of Developing Internal Advertising Regulation

\begin{tabular}{lccc}
\hline \multicolumn{1}{c}{ Action } & Period & $\begin{array}{c}\text { Frequency } \\
\text { Or Duration }\end{array}$ & PIC \\
\hline $\begin{array}{l}\text { Gather data and information about formal } \\
\text { regulation of sleep aid advertisement in }\end{array}$ & September 2021 & Two weeks & Finance \\
$\begin{array}{l}\text { Indonesia } \\
\begin{array}{l}\text { Construct internal advertisement } \\
\text { regulation based }\end{array}\end{array}$ & September 2021 & Three weeks & \\
\hline
\end{tabular}

Second, audience are unaware and hardly recognized content of Savlee. Some of the respondents in this research also mentioned that they never get exposed to Savlee's content in the past 6 month. The caption of Savlee also does not contain crucial information about the product or the brand. Therefore, Savlee should create a content guideline which could increase the effectivity of every content from several perspective including creative perspective, the richness of information in a content, the variety of content, and account activeness.

Table 5: Timeline and PIC of Developing Content Guidelines

\begin{tabular}{llll}
\hline \multicolumn{1}{c}{ Action } & \multicolumn{1}{c}{ Period } & \multicolumn{1}{c}{$\begin{array}{c}\text { Frequency } \\
\text { Or Duration }\end{array}$} & PIC \\
\hline $\begin{array}{l}\text { Create solid content planning as an } \\
\text { implementation of Instagram marketing } \\
\text { strategy }\end{array}$ & October 2021 & $\begin{array}{c}\text { At the End of } \\
\text { Previous Month }\end{array}$ & \\
$\begin{array}{l}\text { Create Instagram caption guidelines } \\
\begin{array}{l}\text { Create brand guideline implementation } \\
\text { specifically for Instagram content }\end{array}\end{array}$ & September 2021 & A week & Two weeks \\
\hline
\end{tabular}

Lastly, One of the obstacles faced by marketing team of Savlee is the insufficient amount of time spend to upload content to Instagram which detain Savlee from posting updated content regularly. The impact of this obstacle is decreasing engagement rate and causing bad algorithm to Savlee's Instagram. To solve this problem, researcher advise the marketing team to utilize Facebook Business Manager which provide several features for businesspeople to plan content posting in bulk. Facebook Business Manager offers "post for later" feature for Instagram Feed and Instagram TV and feature to reply comment and direct message. Therefore, the marketing team of Savlee can save time on posting content and prevent the account from being inactive or rarely posting.

Table 6: Timeline and PIC of Utilizing Facebook Business Manager

\begin{tabular}{|c|c|c|c|}
\hline Action & Period & $\begin{array}{c}\text { Frequency } \\
\text { Or Duration } \\
\end{array}$ & PIC \\
\hline $\begin{array}{l}\text { Learn how to use Facebook Business } \\
\text { Manager }\end{array}$ & October 2021 & One week & \\
\hline $\begin{array}{l}\text { Schedule and plan biweekly content } \\
\text { posting on Facebook Business }\end{array}$ & October 2021 & $2 \mathrm{x} / \mathrm{month}$ & Marketing \\
\hline $\begin{array}{l}\text { Evaluate the result of every content } \\
\text { posted on Instagram }\end{array}$ & October 2021 & $1 \mathrm{x} /$ month & \\
\hline
\end{tabular}

\section{Boost Reach of Savlee's Instagram}

To increase the reachability of Savlee's Instagram in order to increase brand awareness from new potential audience and convert it to sales, Savlee need to focus on generating content which triggers human engagement. One of the weakness of Savlee is lack of content penetration in Instagram Reels which currently grows in Indonesia and possibly helps small business captures new 
DOI: https://doi.org/10.47405/mjssh.v6i9.1014

market. The brand also should focus on capturing a new trend on social media and starting to relate with its audience.

Table 7: Timeline and PIC of Creating High Engagement Content

\begin{tabular}{lccc}
\multicolumn{1}{c}{ Action } & Period & Frequency & PIC \\
\hline Penetrate content on Instagram Reels & October 2021 & $1 \mathrm{x} /$ Week & \\
Capture new trend on social media as an & October 2021 & $1 \mathrm{x} /$ Week & Marketing \\
Instagram content & & \\
\hline
\end{tabular}

\section{Gather Additional Marketing Fund}

One of the biggest obstacles for Savlee to execute more engaging content is fund limitation. Savlee can only optimize the role of content to increase brand awareness and expand the business. Fortunately, all founders have committed to collect additional funds to help the business allocate budget on more effective and engaging strategy.

Table 8: Timeline and PIC of Collecting Fund from Founders

\begin{tabular}{llcc}
\multicolumn{1}{c}{ Action } & Period & Frequency & PIC \\
\hline $\begin{array}{l}\text { Determine the amount of funding that } \\
\text { will be collected from Founders }\end{array}$ & September 2021 & Two weeks & Finance and \\
$\begin{array}{l}\text { Determine the return of investment and } \\
\text { return period }\end{array}$ & September 2021 & One time event & All Founders \\
\hline
\end{tabular}

\section{Resource Requirement of Implementation Plan}

With the limitation of financial capability, the researcher has ensured most of strategies proposed are affordable to be executed. However, some of solutions are absolutely impossible to be executed as planned without financial support. It still requires capital with relatively affordable budget for small business like Savlee. Hence, Savlee should set up initial marketing budget to get these solution be penetrated to the market.

Table 9: Capital Fund to Execute Action Pelan

\section{Solution}

Join sleeping issue online community

Conduct internal marketing training using online paid courses

Hire unpaid graphic designer and video editor interns

Develop internal content advertising regulation

Develop content guidelines for Instagram marketing strategy

Utilize Facebook Business Manager for content scheduling

Create high engagement content

Collect fund from Founders

\section{Total capital needed}

\section{Capital Needed}

IDR 0 ,-

IDR 450.000,-

IDR $0,-$

IDR $0,-$

IDR $0,-$

IDR 0 ,-

IDR 900.000,-

IDR 0,-

Aside from the capital needed, Savlee should manage the teams to carry out this Instagram marketing plan with a high commitment. Savlee which current be handled by four employees should optimize individual skills in business acumen, team management, project management, and communication to ensure each person in the team take the role responsibly. Moreover, Savlee also additional team member in graphic designing and video editing to ensure this strategy could effectively be implemented 


\section{Conclusion}

As a business which use social media as its main channel to promote the brand and products, online presence and the penetration of content become arrowhead of effective Instagram marketing strategy. From the previous analysis, it is clear that Instagram marketing strategy which had been carried out by marketing team of Savlee is ineffective to increase brand awareness nor sales. It also does not show a significant impact on the growth of Instagram account of Savlee as main channel of this business. Therefore, there are several strategies that can be executed by Savlee to solve this situation including joining online sleeping issue community, conduct internal marketing training using online paid course, hire graphic designer and video editor interns, develop internal content advertising regulation and content guideline, utilize Facebook Business Manager, create high engagement content, and collect fund from Founders. In order to penetrate these strategies optimally, the company should prepare IDR1.350.000, - and each individual in the company should increase their skills on business acumen, team management, project management, and communication. It also takes dedication and high commitment to ensure each action plan is run as scheduled and gain expected result.

\section{References}

Detik Health. (2010). 28 Juta Orang Indonesia Terkena Insomnia. [Online] Available at: https://health.detik.com/berita-detikhealth/d-1349258/28-juta-orang-indonesiaterkena-insomnia [Accessed 24 May 2021].

Doggett, A., 2005. Root Cause Analysis: A Framework for Tool Selection. Quality Management Journal, vol. 12, no.4, pp.34-45.

Grant, C. \& Osanloo, A. (2014). Understanding, Selecting, and Integrating a Theoretical Framework in Dissertation Research: Creating the Blue print for 'House.' Administrative Issues Journal: Connecting Education, Practice and Research. Vol. 4, pp. 12-22

Musonera, E. (2018). Instagram: A Photo Sharing Application. Journal of the International Academy for Case Studies, 24(4), pp. 1-9.

Rapp, A. et al., 2013. Understanding Social Media Effect across Seller, Retailer, and Consumer Interaction. Journal of the Academy of Marketing Science, 41(5), pp. 547-566.

Sleep Association. (2021). Sleep and Sleep Disorder Statistic. [Online] Available at: https://www.sleepassociation.org/about-sleep/sleep-statistics/ [Accessed 27 June 2021]. 